\title{
Censusing Laysan Ducks Anas laysanensis: a lesson in the pitfalls of estimating threatened species populations
}

\author{
ANN P. MARSHALL
}

\section{Summary}

The Laysan Duck Anas laysanensis is a threatened species endemic to Laysan Island, Hawaii, U.S.A., with a population that appears subject to severe fluctuation, although this may be attributable to different census methods. The most effective method used so far has been one that notes the ratio of marked to unmarked birds seen on censuses conducted at dusk around the central lake. In 1986 and 1987, weekly censuses were made from which population estimates were derived with the Lincoln-Petersen Index: the current population is approximately 500. The ducks were least visible during the nesting and moulting periods of spring and summer, and population estimates were significantly lower during that period in both 1986 and 1987. This phenomenon calls in doubt other estimates and probably accounts for the fluctuations noted in previous years. Thus careful attention should be given to potential problems in monitoring threatened species populations, because without a clear understanding of the ecology of the threatened species, population estimates could suggest inappropriate management measures.

\section{Introduction}

The Laysan Duck Anas laysanensis is endemic to Laysan Island, a remote island in the Hawaiian Archipelago (U.S.A.) located $1,463 \mathrm{~km}$ west-north-west of Honolulu, Oahu. The Laysan Duck, also called the Laysan Teal because of its small size, was near extinction in the late 1800 s and early 1900s, partly due to shooting for sport and food by guano-miners and feather-hunters, and partly due to the decimation of vegetation by introduced rabbits Oryctolagus cuniculus (Bailey 1919, Ripley 1960, Warner 1963, Kear 1977, Weller 1980). Although Laysan Island, along with other leeward Hawaiian islands, was set aside by Theodore Roosevelt in 1909 as part of the Hawaiian Islands Bird Reservation (Warner 1963, Berger 1972), protection of the duck population continued to be inadequate and ducks continued to be killed by plumage-hunters (Berger 1972, Halliday 1978, Moulton and Weller 1984). In addition, the rabbits continued to increase and destroy the vegetation despite efforts to eradicate them (Bailey 1919, Berger 1972). By the time the rabbits were finally eliminated in 1923, the island was almost devoid of vegetation (Warner 1963, Kear 1977), three of the island's bird species had gone extinct (Ripley 1960), and two other species, the Laysan Finch Telespyza cantans and the Laysan Duck, had almost been lost. The duck continues today on the Endangered Species List (U.S. Fish and Wildlife Service 1982, Moulton and Weller 1984), largely because it is restricted to one very small 
island where it is vulnerable to human intrusion, extreme weather conditions such as storms or droughts, and the potential introduction of harmful species. Figure 1 illustrates the decline of ducks on Laysan in the late 1800 , even before rabbits were introduced, at the time guano-miners were present on the island, but the population continued to fluctuate even after the miners, feather-hunters and rabbits were gone. Table 1 presents the counts and estimates of ducks on Laysan from 1970 to 1980 , illustrating that the number of ducks apparently continues to fluctuate. Most of the "estimates" in Table 1 were based on the actual numbers of ducks seen and therefore included no confidence intervals (Moulton and Weller 1984).

Table 1. The number of Laysan Ducks seen, or population estimate of Laysan Ducks on Laysan Island, since 1970

\begin{tabular}{llll}
\hline Year & Month & \multicolumn{1}{c}{ Ducks counted or estimated } & \multicolumn{1}{c}{ Source } \\
\hline 1970 & August & 50 (lake count) & Sincock and Kridler (1977) \\
1971 & September & 149 (lake count) & Sincock and Kridler (1977) \\
1972 & September & 162 (lake count) & Sincock and Kridler (1977) \\
1973 & July & 25 (highest of 5 lake counts) & Sincock and Kridler (1977) \\
1974 & July & 69 (highest of several lake counts) & Sincock and Kridler (1977) \\
1975 & August & 251 (highest lake count) & Sincock and Kridler (1977) \\
1976 & March & 103 (lake count) & Sincock and Kridler (1977) \\
& May & 100 (lake count) & Sincock and Kridler (1977) \\
& August & 287 (lake count) & Sincock and Kridler (1977) \\
1979 & & 510 estimated by Lincoln-Petersen & Moulton and Weller (1984) \\
& & Index (LPI) & \\
1980 & & (454 adults, 8 young banded) & \\
\hline
\end{tabular}

Although the relative accuracy of these counts and estimates cannot be judged, it is believed that numbers of ducks counted around the turn of the century err on the low side (Sincock and Kridler 1977). Counts through the 1910 s and 1920 s were probably quite accurate, because during those years the birds could easily be seen owing to lack of vegetation. Counts after 1923 suggest a steady increase in the duck population as the island revegetated, though the number of birds apparently remained low (Ely and Clapp 1973). Counts in the 1930 s and early 1950 s resulted from cursory observations during brief visits to Laysan by observers with little or no experience with Laysan Ducks. Therefore these estimates probably also err on the low side (Sincock and Kridler 1977). No counts are known from the 1940s (Sincock and Kridler 1977).

Estimates in the late 1950 s and early 1960s used the transect method, and probably erred on the high side because these estimates were calculated using the entire vegetated area (estimated as $283 \mathrm{ha}$ ) of the island as the potential sampling universe. However, the Nama (a small perennial herb) association of vegetation is utilized only rarely by the ducks, and removing this from the calculation reduces the utilized vegetated area to 187 ha (Sincock and Kridler 1977). 


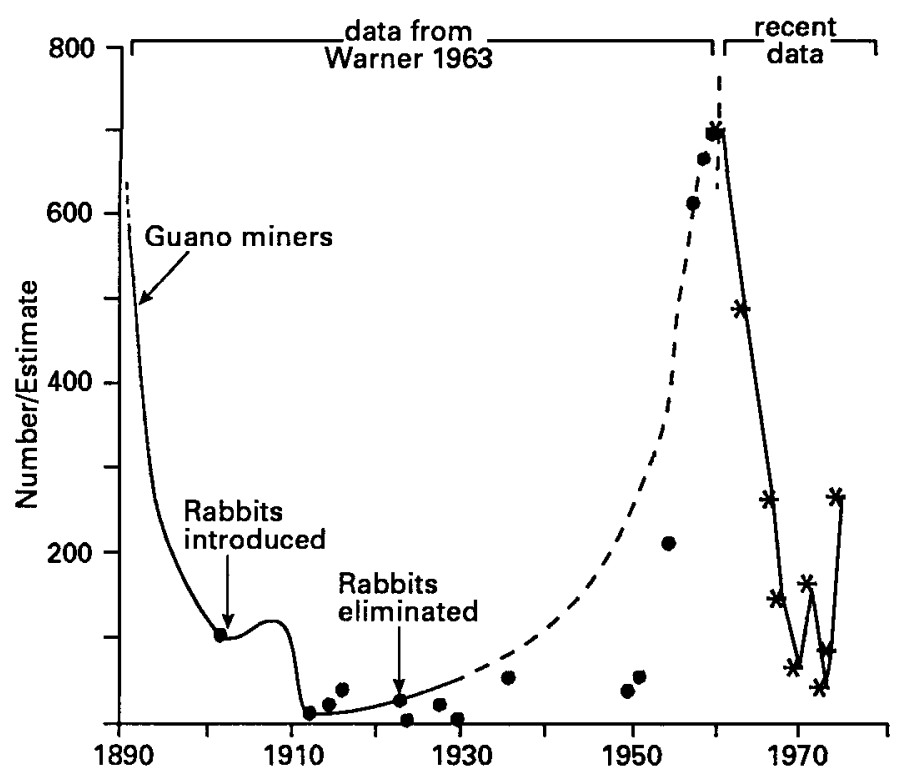

Figure 1. Numbers of Laysan Ducks in the wild from 1890 to 1974. Solid circles indicate published counts (from Warner 1963). Recent counts, indicated by asterisks, were made by the Hawaiian Wildlife Service personnel (after Kear 1977, and reproduced with kind permission from the International Zoo Yearbook).

In 1982, a recovery plan for the Laysan Duck was approved by the U.S. Fish and Wildlife Service (USFWS). The objective of this plan is to decrease the vulnerability of the species's population through careful management of its habitat, yearly monitoring of its numbers, and continued captive breeding. The USFWS in Hawaii is responsible for monitoring the wild population. Laysan Ducks are considered the most difficult to survey of the four endangered bird species of the north-western Hawaiian Islands, and a satisfactory method for estimating the population had not been developed by the 1970s (Sincock and Kridler 1977, Moulton and Weller 1984). Methods have included "beatouts" by four or five people walking abreast in the vegetation around the lake, transects of the vegetated parts of the island, and counts conducted by walking around the central lake at various times of day. Beatouts were originally considered the best method, but lake counts conducted at the same hours (at dusk) resulted in larger totals of ducks. The transect method was found to be of little utility when the duck population was low; often observers recorded no ducks at all.

Censusers on Laysan are confronted by an island covered with ground- and shrub-nesting birds and riddled with the burrows of petrels and shearwaters. Walking through the vegetation is extremely detrimental to the birdlife. Stepping into a burrow often harms the adults and destroys eggs or chicks. If incubating birds are flushed, the unattended eggs are subject to destruction by the Laysan Finch. Primarily for this reason, the transect method is not considered a good alternative for counting Laysan Ducks (S. Fefer verbally 1986). Moulton 
and Weller (1984) also found it difficult to estimate Laysan Duck populations. They found that line transects during the day were not effective because the ducks did not flush readily and were difficult to see in Eragrostis, a favoured resting cover. Also, some heavily used cover types, Pluchea and Scaevola, were virtually impenetrable to the censusers.

Direct lake counts are now considered a better technique because they apparently do detect the majority of the population (Sincock and Kridler 1977, Moulton and Weller 1984). Additional confusion has resulted because such direct counts around the lake were conducted at different times of the day or year and by different researchers (Ely and Clapp 1973), making the resultant population estimates difficult to compare. During the summers of 1986 and 1987, I studied the reproductive activities of the Laysan Duck, many of which I caught and banded. This paper presents lake counts from these two years and derives estimates from the counts based on the ratio of marked to unmarked ducks.

\section{Methods}

\section{Study site}

Laysan Island is one of the older and larger of the north-western Hawaiian Islands (Ely and Clapp 1973, Moulton and Weller 1984) (Figure 2). It is a low coral sand island of approximately 370 ha (Ely and Clapp 1973). The highest rims of the island are $12 \mathrm{~m}$ above sea level and slope down to a central lake (Lamoureux 1963, Caspers 1967). The hypersaline central lake has no connection to the ocean and although its surface area varies with season and rainfall (Ely and Clapp 1973) it is approximately $1.6 \mathrm{~km}$ long and $0.5 \mathrm{~km}$ wide when full (Moulton and Weller 1984). Evaporation and the continual addition of ocean water by waves washing over the east slopes during winter storms have led to the hypersaline nature of the lake (Warner 1963, Caspers 1967, Moulton and Weller 1984). To protect the island habitat and species, access to Laysan is restricted to those with official or scientific business (Ely and Clapp 1973).

The vegetation of Laysan is typically Hawaiian in character and highly endemic (Lamoureux 1963, Moulton and Weller 1984). There are relatively few plant species, a condition typical of most low oceanic islands; six distinct associations of low shrubs, herbs, morning glory, sedges, and grasses occur in roughly concentric belts around the lake (Lamoureux 1963). Although there have been significant changes in the composition of the flora since the island was first discovered, the current structure of the vegetation is believed to be similar to the distribution of vegetation before the introduction of rabbits (Lamoureux 1963, 1985, Warner 1963). Laysan Island currently has a total of 17 nesting seabird species, including albatrosses, boobies, shearwaters, petrels and terns, as well as the Laysan Finch and the Laysan Duck.

\section{Study species}

The Laysan Duck, the only species of duck on Laysan Island, is dark brown with a purple-greenish speculum and a prominent white eye-ring (Figure 3). 


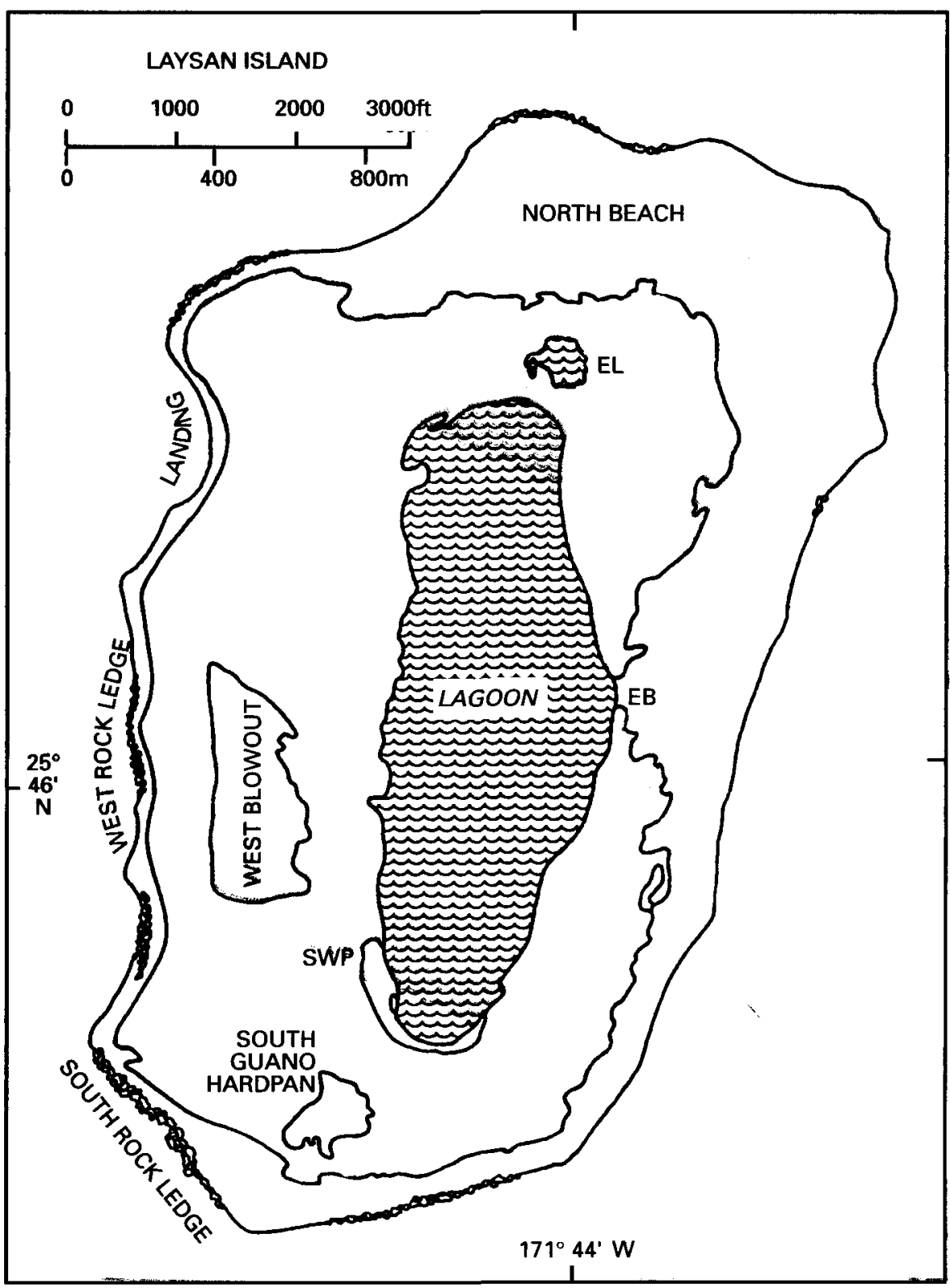

Figure 2. Laysan Island, Hawaii. EL, ephemeral lake; EB, east blowout; the lagoon is referred to as the central lake in the text.

Based on the speculum, feather patterns, bill colour, the drake's upturned central tail-feathers, and major breeding displays, the species has been considered a derivative of the Mallard Anas platyrhynichos, either independently derived from Mallard isolates or secondarily derived from the Koloa, also called the Hawaiian Duck, Anas wyvilliana (Warner 1963, Lack 1970, Weller 1980). How- 


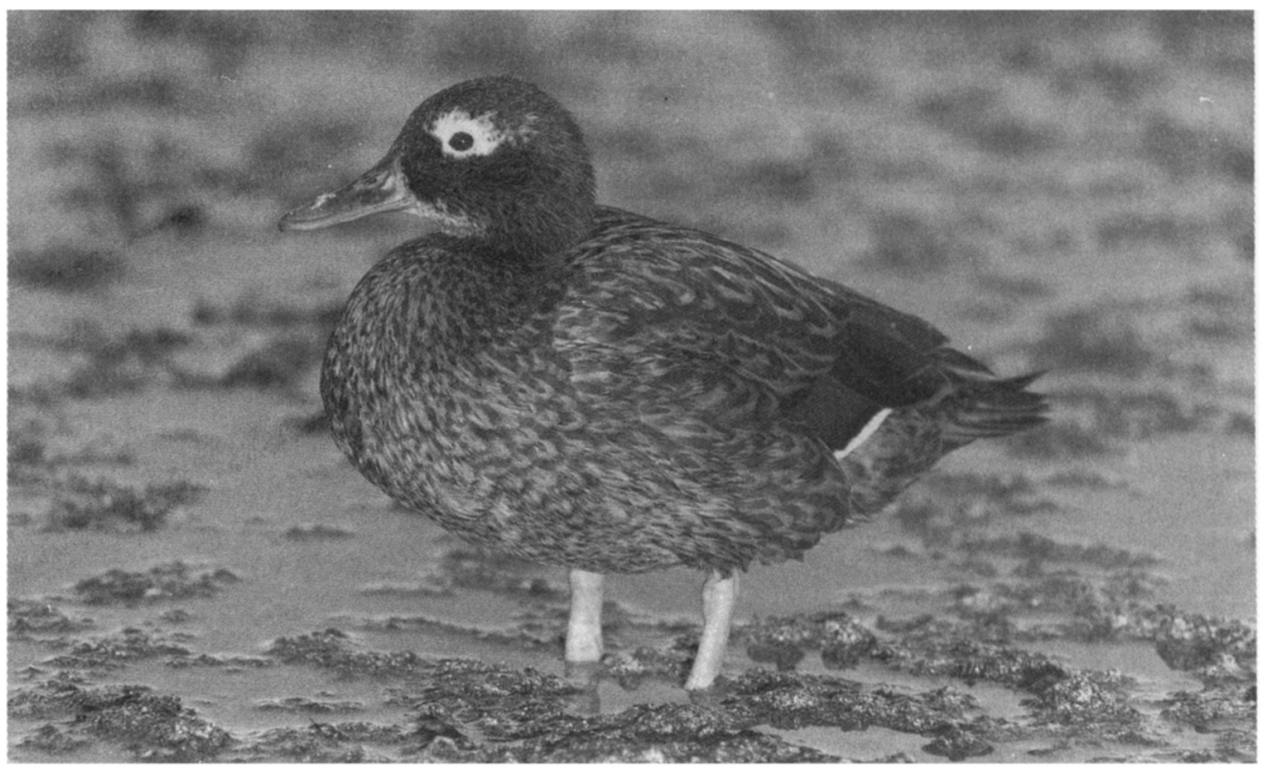

Figure 3. Laysan Duck on Laysan Island.

ever, recent genetic evidence now suggests that the Laysan Duck, Koloa, and Mallard are separate species and that the Laysan Duck and Koloa arose from different lineages. Based on mitochondrial DNA studies, the Laysan Duck groups with the New Zealand Grey Duck Anas superciliosa superciliosa and the Australian Black Duck A. s. rogersi while the Koloa, though closely related to the Mallard, is virtually identical to the North American Mottled Duck Anas fulvigula (J. M. Rhymer in litt. 1991).

\section{Marking}

Ducks were captured throughout the field season, mainly on dark nights as most were too wary to catch on bright nights or during the day. Headlamps were used to locate the ducks and long-handled nets were used to capture them. All captured birds were sexed, banded with USFWS bands (males on the right, females on the left) and uniquely colour-marked (females on the right and males on the left). These bands were readily observable on census, even in the moonlight (although individual colours were usually not distinguishable) and frequently without binoculars, as the ducks are quite unwary. Two hundred ducks were banded in 1986 and 71 in 1987.

\section{Censuses}

I conducted weekly censuses by walking around the central lake during the hour before sunset and noting all ducks seen. The lake was divided into four quadrants $(\mathrm{N}, \mathrm{S}, \mathrm{E}, \mathrm{W})$ and approximately 15 minutes were spent walking through each quadrant. Once a month, a census was carried out from approximately 23 hoo to 24 hoo on the first relatively cloud-free night during the full- 
moon period. By noting the numbers of marked and unmarked birds, I was able to estimate the population using the Lincoln-Petersen Index (LPI) (Davis and Winstead 1980). During most censuses, I was unable to determine whether some birds were banded, either because the ducks were in the water or because of declining light intensity. These birds were not included in the LPI calculations.

Warner (1963) described the ducks as largely nocturnal. During the day, especially when the weather is hot and clear, Laysan Ducks seek cover by midmorning and rest out of sight under dense stands of shrubs, grasses and other vegetation (Warner 1963, Moulton and Weller 1984, pers. obs.). In the late afternoon and evening, the ducks come to the central lake shoreline where they feed on brine flies Neoscatella sexnotata or forage for brine fly larvae and perhaps brine shrimp Artemia salina in the lake. The ducks also congregate at freshwater seeps along the fringes of certain areas of the lake, and during the breeding season there is frequent courtship activity along the shores and in the lake. Moulton and Weller (1984) found through time-lapse photography in 1980 that the highest concentrations and activity of Laysan Ducks occurred between o5hoo and oghoo and between 17 hoo and 21 hoo. They also derived population estimates by observing the ratio of marked to unmarked birds seen at the lake at dusk.

The Laysan Duck is noted for its tameness and reluctance to fly (Fisher 1903, Munro 1944, Bailey 1956, Warner 1963, Berger 1972, Weller 1980). The birds typically do not flush when an observer walks past quietly. Conducting a census around the lake did not appear to affect the behaviour of the ducks.

In 1986, censuses were begun in February and continued through to August for a total of 14 dusk and four full-moon censuses. Censuses were not carried out from 23 May to 26 June owing to flooding of the lake. In 1986, 13 of the dusk censuses were conducted counter-clockwise, starting at the ephemeral lake (EL, Figure 2), and one census (8 May) was begun at the north end of the lake and also conducted counter-clockwise. The four full-moon censuses were conducted clockwise and were begun at the east blowout (EB, Figure 2) (23 February, 24 March), or at the north end of the lake (23 May, 18 July).

In 1987, I began censuses in April and continued through to the first week of September a total of 22 dusk and five full-moon censuses. The starting point $(\mathrm{N}, \mathrm{S}, \mathrm{E}, \mathrm{W})$ and the direction of travel (clockwise, counter-clockwise) were randomized, with the restriction that by the eighth and again by the sixteenth census both directions of travel were used for each starting point. This scheme was followed for the remaining six censuses in which all four starting points were used at least once. In no case did I travel in the same direction from the same starting point more than once. This procedure was followed to avoid possible order effects. All 1987 full-moon censuses were begun at the north end of the lake and only the direction of travel was randomized, with the restriction that the direction of travel for odd-numbered censuses was determined with a random numbers table and that the direction of travel for each even-numbered census was opposite to that of the preceding census. 


\section{Results}

In 1986, only the final eight censuses would allow calculation of the LPI since banding of ducks did not begin until May. However, I judged that meaningful population estimates could not be made from the 8 May and 15 May censuses because only 11 and 40 ducks, respectively, had been banded by those dates. Therefore, only the final six counts were used to calculate LPI population estimates (Figure 4).
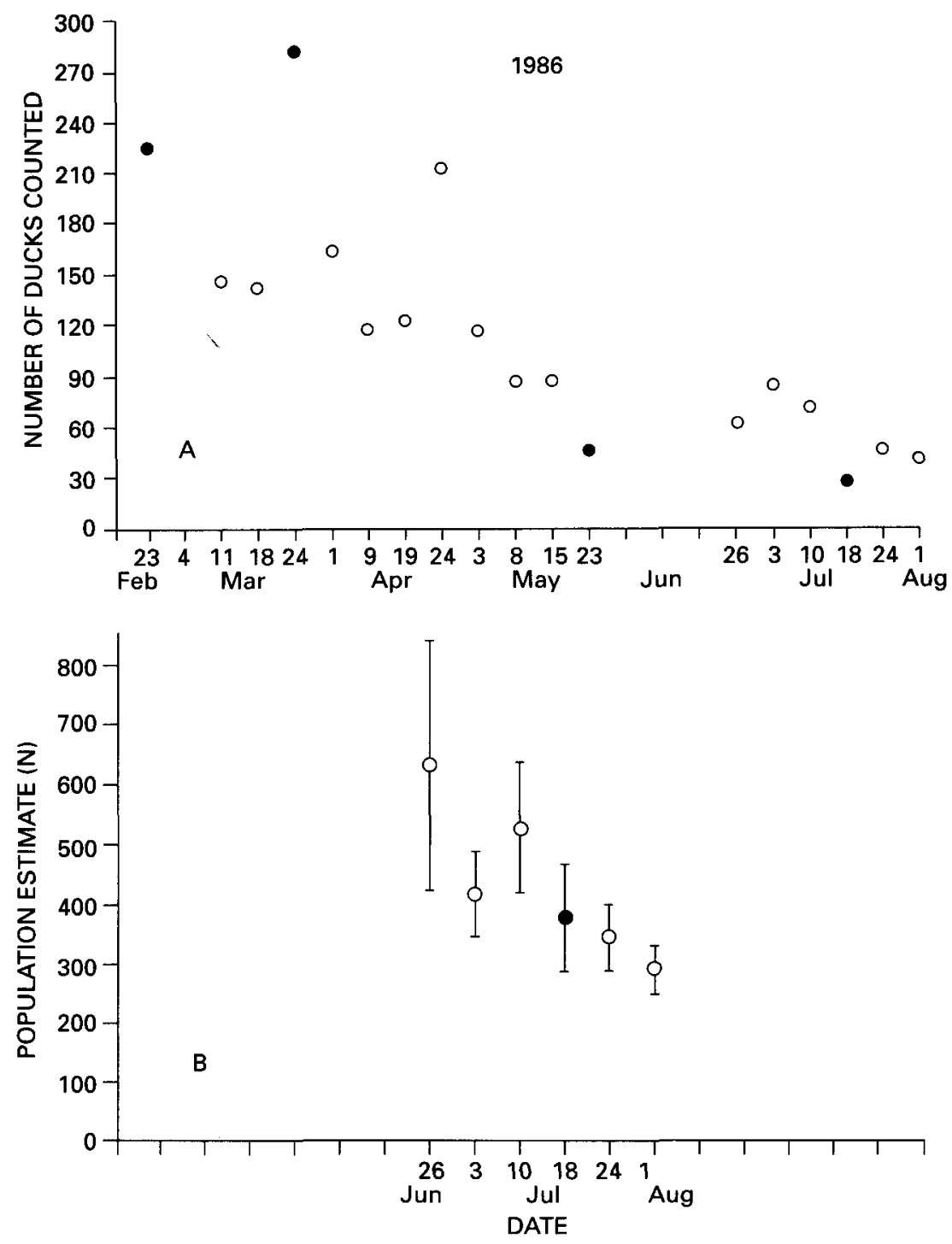

Figure 4. A. The number of Laysan Duck adults counted on lake censuses at dusk in 1986. Filled circles represent full-moon counts. B. Estimates of the population size of adult Laysan Ducks derived from the Lincoln-Petersen Index for 1986 counts. Circles represent the population estimate and vertical lines the $68 \%$ confidence interval. The filled circle represents a full-moon count. 

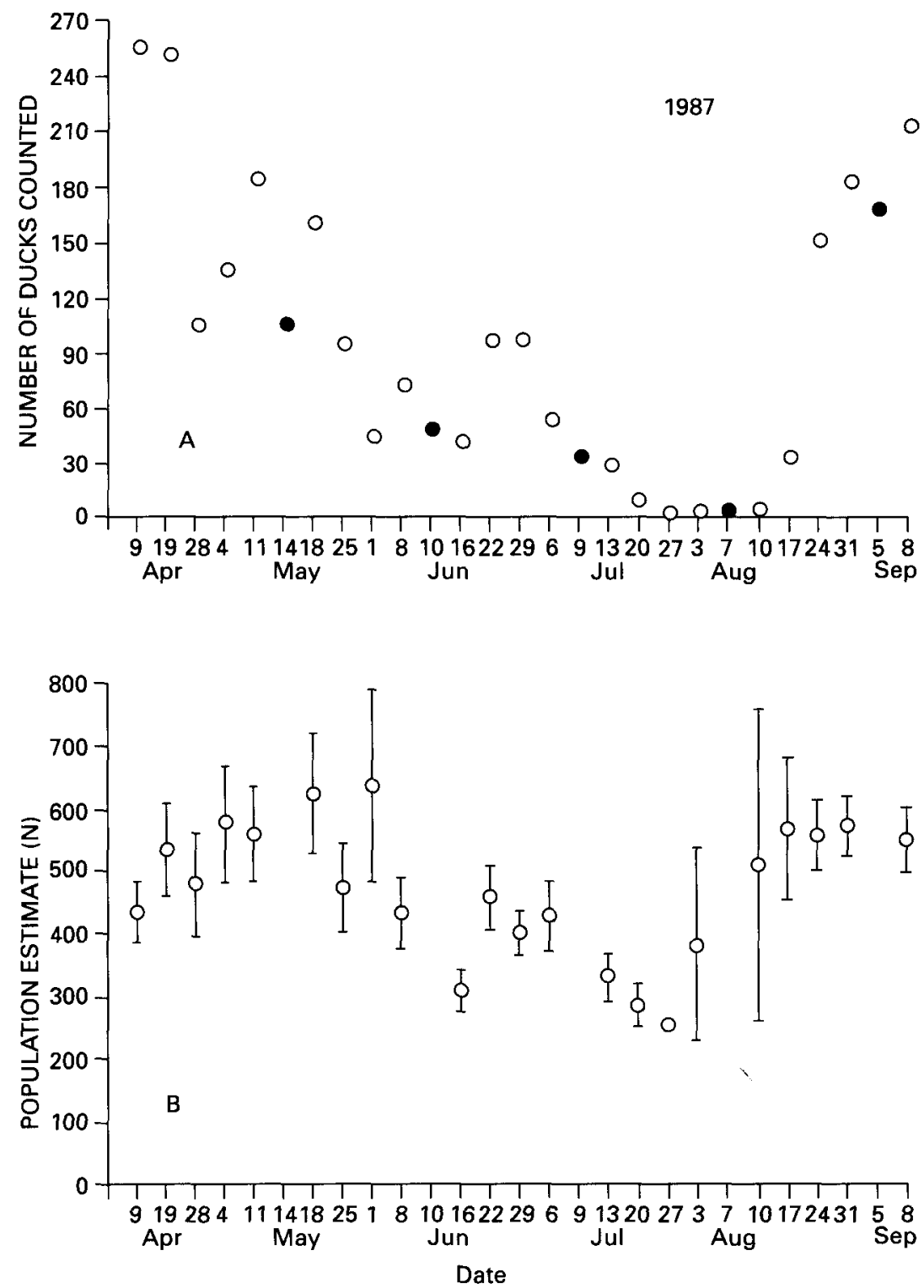

Figure 5. A. The number of Laysan Duck adults counted on lake censuses at dusk in 1987. Filled circles represent full-moon counts. B. Estimates of the population size of adult Laysan Ducks derived from the Lincoln-Petersen Index for 1987 counts. Circles represent the population estimate and vertical lines the $68 \%$ confidence interval. Note that none of the full-moon counts was used in the population estimate.

The numbers of adult ducks counted on weekly censuses from February to August 1986 are depicted in Figure $4 \mathrm{~A}$. There was a decrease in ducks seen around the lake throughout the summer $\left(r_{\mathrm{s}}=-0.902, P=0.0001\right.$, two-tailed). Figure $4^{B}$ shows the population estimates calculated from the last six censuses 
during 1986. There was a significant decline in the estimated population of ducks later in the season $\left(r_{\mathrm{s}}=-0.943, P=0.0005\right.$, two-tailed). The mean population estimate for these six 1986 censuses was $423 \pm 128$.

Figure $5 \mathrm{~A}$ shows the number of ducks counted in 1987. There was again a significant decline during the summer $\left(r_{\mathrm{s}}=-0.873, P=0.0001\right.$, two-tailed). To compare these counts with the 1986 data, I used only censuses through to 27 July as this was closest to the date of the last count in 1986.

The 1987 population estimates (through to 27 July), as in 1986, showed a significant decline $\left(r_{\mathrm{s}}=-0.7315, P=0.0012\right.$, two-tailed; Figure $\left.5 \mathrm{~B}\right)$. During August and September 1987, the number of ducks seen on census increased rapidly and the estimates also increased for the last two months. The mean population estimate for all 22 (dusk) censuses conducted in 1987 was $466 \pm 110$. When the data were grouped according to when the number of ducks seen on census began to decline or increase, the 9 April to 1 June mean population estimate was $538 \pm 73$, the 8 June to 3 August mean population estimate was $360 \pm 73$, and the 10 August to 8 September mean population estimate was 543 \pm 25 .

On 25 May 1987; a Laysan Finch census was conducted by transect during which Laysan Duck sightings were also noted. Five ducks were seen on census. The population was estimated to be $170 \pm 148$ ( $90 \%$ confidence interval). The population size was estimated with the formula $(\Sigma X / n)\left(l^{-1}\right)(A)$ where $\Sigma X$ is the total number of ducks counted (5) on all transects, $n$ is the number of transects (120), $l$ is the area of each $91.4 \mathrm{~m}$ long, $5.0 \mathrm{~m}$ wide transect $\left(460 \mathrm{~m}^{2}\right)$, and $A$ is the total area of vegetated land on the island $\left(1.88 \times 10^{6} \mathrm{~m}^{2}\right)$.

\section{Discussion and management implications}

Extreme fluctuations in the estimated numbers of ducks on Laysan have been noted since the 1950s. Counts have ranged from 25 to 462 and estimates from 133 to 594 (U.S. Fish and Wildlife Service 1982). These apparently large and rapid fluctuations in population have been postulated as being due to periodically severe storms (Berger 1970, Halliday 1978, Kear and Williams 1978), inbreeding (Zimmerman 1970), and the amount of water and salinity of the central lake, factors that determine the quantity of food available (Kear and Williams 1978, Todd 1979, U.S. Fish and Wildlife Service 1982). More recently, these fluctuations have been thought to be due to an inability to count all birds present (U.S. Fish and Wildlife Service 1983), differing survey techniques used in different years of censuses (U.S. Fish and Wildlife Service 1982, Moulton and Weller 1984), and, possibly, seasonal variation in the behaviour of the ducks (Moulton and Weller 1984, this study). In this study, an estimate of 170 ducks was obtained on 25 May 1987 with the transect method, in contrast to the 28 May lake count which yielded an estimate of 470 . That the transect method erred on the low side is obvious in light of the 9 April 1987 lake count in which 255 ducks were actually counted. Thus, in addition to being detrimental to the populations of other birds nesting on the island, the transect method appears to be less accurate, as has been suggested previously (Sincock and Kridler 1977, Moulton and Weller 1984) although it might be possible to improve this census technique using LPI and/or a detectability coefficient. 
The decline in numbers of ducks seen from June to August in 1986 and 1987 clearly did not reflect a substantial decline in the size of the population, but was a consequence of the behaviour of the ducks during this period. Laysan Ducks are non-migratory and there has been no recorded occurrence of freeranging birds off Laysan Island (Warner 1963, Moulton and Weller 1984). The breeding season lasts from February through to July (Berger 1972, Johnsgard 1978) and broods in the wild have been reported from March to September (Fisher 1903, Ely and Clapp 1973, Moulton and Weller 1984). Individual females have been found incubating from early spring into summer, and some may renest. Females on nests sit tightly and were rarely seen during the present study. They appeared to feed less frequently while incubating and then only for short periods, so they were unlikely to be seen at the lake during census periods. Males begin to moult around the start of June, and females in July and August. The earliest females to moult appear to be those with no young. When the ducks are moulting, they tend to be very wary and will hide upon approach, unlike other times when they are very tame. They are rarely seen at the lake when moulting, nor do they then flush readily from the vegetation (Moulton and Weller 1984, pers. obs.).

For these reasons, accurate population estimates will be difficult to obtain during the spring and summer months when incubation and moulting are occurring. The LPI does not compensate for this, as an assumption of this index, equal probability of being recaught (seen on census) or no change in the visibility of animals between marking and recapture, is violated (Davis and Winstead 1980). While nearly equal numbers of males and females were caught and banded in the spring, mostly females were caught in the summer as they remain with the ducklings around the lake even if moulting, whereas moulting males move into the vegetation. The increase in ducks seen on census beginning in late August/early September was not due to the recruitment of young, as only adults were included in this estimate. (Juveniles are readily distinguished from adults by plumage characteristics until late autumn - pers. obs.) The increase in ducks is due rather to moulted birds no longer hiding in the vegetation. These data also make other estimates of Laysan Ducks highly suspect and may account for the fluctuations in numbers noted in previous years.

To obtain the most accurate population estimates, one should conduct censuses when the ducks are most visible. During the fall and winter, Laysan Ducks begin to court and pair (Warner 1963, pers. obs.) and because they are active, unwary, and quite visible then, it might be possible to obtain accurate population estimates at that time. Census information from other times of the year can be useful and should be obtained whenever possible. The USFWS frequently has personnel on the island for only short periods; it is important to have baseline data from all times of the year, so that if, for example, only 10 ducks were seen on a census on 20 July 1990, researchers would be able to look at previous data indicating that low numbers of ducks in July do not necessarily indicate a decline in the population, but may simply reflect their secretive behaviour during the summer months of incubation and moulting. It is therefore advisable to conduct estimates several times a year to determine more accurately the size of the population. 
Moulton and Weller (1984) estimated a population of 510, which they thought probably represents the contemporary carrying capacity of habitat on Laysan. Over $90 \%$ of the ducks on Laysan were banded in 1979 and 1980 (502 birds), suggesting the LPI was relatively accurate in estimating the population. The data from this study (1986 and 1987) also indicate a population of about 500 ducks.

In conclusion, several findings bear on the interpretation of future counts of Laysan Ducks. The apparently severe fluctuations in numbers in recent years may be partly caused by the use of several methods of counting, lack of knowledge about the behaviour and ecology of the species, and variation in the time of year when the birds were counted. The most accurate method of tracking the population is probably by calculating estimates based on the ratio of marked to unmarked ducks counted during dusk censuses around the lake. Accurate population estimates cannot be obtained during the spring and summer when incubation, duckling care, and moulting occur. During fall to early spring when Laysan Ducks are courting and pairing they are highly visible; therefore it would be useful to determine the accuracy of counts undertaken at this time in relation to counts made during the rest of the year. However, ideally censuses would be obtained throughout the year to track the health of the population. In addition, banding efforts should be continued yearly.

This is intended to be a cautionary note on some of the pitfalls of estimating populations of endangered species. Although in this instance the lesson is not derived from painful experience, clearly, without a thorough understanding of a species's ecology, one could easily arrive at erroneous population estimates which could suggest inappropriate management measures.

\section{Acknowledgements}

Funding for this project was provided in part by grants from the Hawaii Audubon Society and the Mount Holyoke College Ira Skillman Stryker Fellowship. Technical and logistical support and some of the census data were provided by the U.S. Fish and Wildlife Service in Hawaii. The NOAA ship, Townsend Cromwell, provided transportation to Laysan and aid with field camps. For their support and/or field assistance, I am grateful to Doris Alcorn, Ed Bean, Brenda Becker, Patrick Ching, Stewart Fefer, Darcy Hu, Kathryn Keller, Kathryn Marshall, Robert Marshall, Larry Martin, Ken McDermond, Marie Morin, Mark Scheffel, Lou Sileo, Thomas Waite and Robin Westlake. An earlier version of this manuscript was substantially improved by comments from Thomas $C$. Grubb, Jr., Theodore A. Bookhout, David A. Stansbery, Thomas A. Waite, Jeffrey M. Black, Andy Green and Alison J. Stattersfield.

\section{References}

Bailey, A. M. (1919) Notes on our Hawaiian reservation. Natural History 19: 382-395. Bailey, A. M. (1956) Birds of Midway and Laysan Islands. Denver Mus. Nat. Hist., Mus. Pict. 12.

Berger, A. J. (1970) The present status of the birds of Hawaii. Pacific Sci. 24: 29-42.

Berger, A. J. (1972) Hawaiian birdlife. Second edition. Honolulu: University Press of Hawaii. 
Caspers, H. (1967) Biology of a hypersaline lagoon in a tropical atoll island (Laysan). Pp.326-333 in R. Misra and B. Gopal, eds. Proceedings of the symposium on recent advances in tropical ecology. Varanasai, India: The International Society for Tropical Ecology.

Davis, D. E. and Winstead, R. L. (1980) Estimating the numbers of wildlife populations. Pp.221-245 in S. D. Schemnitz, ed. Wildlife management techniques manual. Fourth edition, revised. Washington, D.C.: The Wildlife Society.

Ely, C. A. and Clapp, R. B. (1973) The natural history of Laysan Island, northwestern Hawaiian Islands. Atoll Res. Bull. 171: 1-361.

Fisher, W. K. (1903) Birds of Laysan and the leeward islands, Hawaiian group. Bull. U.S. Fish Commission 23: 767-807.

Halliday, T. (1978) Vanishing birds: their natural history and conservation. London: Sidgwick and Jackson.

Johnsgard, P. A. (1978) Ducks, geese and swans of the world. Lincoln, Nebraska: University of Nebraska Press.

Kear, J. (1977) The problems of breeding endangered species in captivity. Internatn. Zoo Yearbook 17: 5-14.

Kear, J. and Williams, G. (1978) Waterfowl at risk. Wildfowl 29: 5-21.

Lack, D. (1970) The endemic ducks of remote islands. Wildfowl 21: 5-10.

Lamoureux, C. H. (1963) The flora and vegetation of Laysan Island. Atoll Res. Bull. 97: 1-14.

Lamoureux, C. H. (1985) Restoration of native ecosystems. Pp.421-431 in C. P. Stone and J. M. Scott, eds. with assistance of D. B. Stone and A. R. Komenaka. Hawai'i's terrestrial ecosystems: preservation and management. Honolulu: University of Hawaii.

Moulton, D. W. and Weller, M. W. (1984) Biology and conservation of the Laysan Duck (Anas laysanensis). Condor 86: 105-117.

Munro, G. C. (1944) Birds of Hawaii. Honolulu: Tongg Publishing Company.

Ripley, S. D. (1960) Laysan teal in captivity. Wilson Bull. 72: 244-247.

Sincock, J. L. and Kridler, E. (1977) The extinct and endangered endemic birds of the northwest Hawaiian Islands. Unpublished (118 pp.).

Todd, F. S. (1979) Waterfowl: ducks, geese and swans of the world. San Diego: Sea World Press.

U.S. Fish and Wildlife Service (1982) The Laysan Duck recovery plan. Portland, OR.

U.S. Fish and Wildlife Service (1983) Recovery plans for Laysan Duck, Sonoran pronghorn approved. Endangered Species Techn. Bull. 8: 6.

Warner, R. E. (1963) Recent history and ecology of the Laysan Duck. Condor 65: 2-23.

Weller, M. W. (1980) The island waterfowl. Ames, Iowa: Iowa State University Press.

Zimmerman, D. R. (1970) To save a bird in peril. New York: Coward, McCann and Geoghegan.

ANN P. MARSHALL

Department of Zoology, Ohio State University, 1735 Neil Avenue, Columbus, OH 4321o, U.S.A. Present address:

The Wildfowl and Wetlands Trust, Slimbridge, Gloucestershire GL2 7 BT, U.K. 